\title{
Endocardectomy for the surgical treatment of endocardial fibrosis of the left ventricle
}

\author{
PA RUSSO, JEC WRIGHT, SIEW YEN HO, JR MANEKSA, D CLITSAKIS \\ From the Department of Cardiac Surgery, London Chest Hospital, and the Cardiothoracic Institute, \\ Brompton Hospital, London
}

ABSTRACT Two patients with endomyocardial fibrosis of the left ventricle were treated by endocardectomy plus mitral valve replacement. In both cases the results of surgery were satisfactory. No consequences related to eosinophilia, which was present before operation in one of them, were noted. The poor prognosis of this progressive disease and the inefficiency of medical treatment compared with the good surgical results already reported from various centres encourage early operation for all patients with endomyocardial fibrosis who have symptoms. Because of the pathophysiology of the disease, endocardectomy should be attempted in all cases and anticoagulant treatment continued for life.

Endocardectomy for the surgical treatment of endomyocardial fibrosis was first described by Gerbaux and colleagues in $1973 .^{1}$ The procedure consists of removal of the fibrotic endocardial shell from the affected ventricular cavity and replacement of the atrioventricular valve that has been rendered incompetent by the fibrosis of the papillary muscles and chordae. In view of the poor prognosis associated with the disease and the limited effects of the medical treatment ${ }^{2}$ surgery represents a safe and reliable alternative procedure for the management of this condition. This study reviews our experience with the surgical treatment of two patients with endomyocardial disease of the left ventricle and mitral incompetence.

\section{Case reports}

CASE 1

A 38 year old man, a Muslim, was admitted in heart failure. He had a resting tachycardia, a systolic blood pressure of $80 \mathrm{~mm} \mathrm{Hg}$, neck vein distension, and parasternal heave palpable to the apex. On auscultation there was a moderate apical pansystolic murmur, wide splitting of the second heart sound, and an additional third heart sound. The chest radiograph showed moderate cardiac enlargement with some pulmonary venous congestion. The elec-

Address for reprint requests: Mr JEC Wright, London Chest Hospital, London E1 9JX.

Accepted 15 February 1985 trocardiogram showed sinus rhythm and left atrial and ventricular hypertrophy. Cardiac catheterisation showed pulmonary hypertension and a high end diastolic left ventricular pressure (table 1 ). Left ventricular cineangiography showed obliteration of the cavity and mitral regurgitation into an enlarged left atrium. He was referred for operation, which consisted of endocardectomy and mitral valve replacement (see under "Surgical procedure"). The postoperative period was uneventful and the patient was discharged on the 25th day in good general and haemodynamic condition. Long term anticoagulant treatment was prescribed. Nineteen months later the anticoagulants were stopped for obscure reasons and he developed right hemiplegia, from which he recovered well. He remained aphasic, however, although his general and cardiac condition was still satisfactory two years after the operation. He was advised to continue the anticoagulants for life.

\section{CASE 2}

A 65 year old man, also a Muslim, was admitted in a poor general and nutritional state. The time of onset of cardiac symptoms could not be determined. He had a low exercise tolerance, progressive dyspnoea, and signs of mitral incompetence. The ECG was normal apart from atrial fibrillation. The chest radiograph showed enlargement of the left atrium and pulmonary congestion. Cardiac catheterisation (table 1) showed pulmonary hypertension and a high end diastolic left ventricular pressure. Left ventricular cineangiography showed cavity obliteration 
Table 1 Catheterisation data

\begin{tabular}{|c|c|c|c|c|c|c|}
\hline & $\begin{array}{l}\text { Mean RAP } \\
(m m \mathrm{Hg})\end{array}$ & $\begin{array}{l}R V P \\
(m m H g)\end{array}$ & $\begin{array}{l}P A P \\
(m m H g)\end{array}$ & $\begin{array}{l}\text { Mean PWP } \\
(m m \mathrm{Hg})\end{array}$ & $\begin{array}{l}L V P \\
(m m H g)\end{array}$ & $\begin{array}{l}A O P \\
(\mathrm{~mm} \mathrm{Hg})\end{array}$ \\
\hline $\begin{array}{l}\text { Patient } 1 \\
\text { Patient } 2\end{array}$ & $\begin{array}{r}12 \\
8\end{array}$ & $\begin{array}{c}100 / 18 \\
75 / 9\end{array}$ & $\begin{array}{r}100 / 50 \\
65 / 25\end{array}$ & $\begin{array}{l}48 \\
22\end{array}$ & $\begin{array}{l}117 \text { edp }=32 \\
110 \text { edp }=20\end{array}$ & $\begin{array}{r}82 / 52(\text { mean } 62) \\
125 / 65(\text { mean } 85)\end{array}$ \\
\hline
\end{tabular}

$R A P$-right atrial pressure; $R V P$-right ventricular pressure; $P A P$ - pulmonary artery pressure; $P W P$-pulmonary wedge pressure;

$L V P$-left ventrcular pressure; $A O P-$ aortic pressure; edp-end diastolic pressure.

with a rigid lining and diseased papillary muscles (fig 1). In addition, there was gross mitral incompetence. The left atrium was enlarged. The white blood cell count showed eosinophilia $\left(1 \times 10^{9} / 1\right)$. The operation consisted of endocardectomy and mitral replacement (see below). A cross sectional echocardiogram performed soon after operation showed poor left ventricular function and pericardial effusion. The patient's condition improved rapidly, however, with digoxin and diuretics, and he was discharged on the 20th postoperative day in a good haemodynamic condition. At that time the eosinophil count was within normal limits $(0.09 \times$ $\left.10^{9} / 1\right)$. Long term anticoagulant treatment was prescribed.

\section{Surgical procedure}

Both patients were operated on through a standard median sternotomy. Both venae cavae and the ascending aorta were cannulated and moderately hypothermic $\left(28^{\circ} \mathrm{C}\right)$ extracorporeal circulation was instituted. Myocardial protection was achieved by ionic cardioplegia. The left atrium was approached through a longitudinal incision behind the interatrial groove. In both cases the mitral valve showed gross chordal retraction due to fibrosis of the tensor apparatus, but normal cusps. The inflow portion of

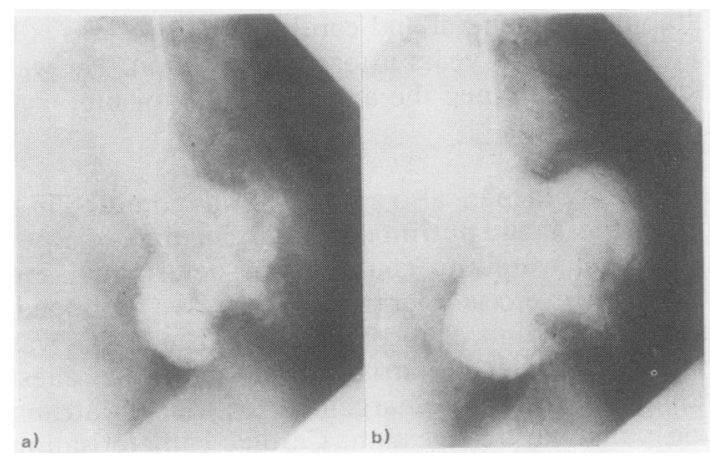

Fig 1 Left ventricular cineangiogram from patient 2 showing obliteration of the left ventricular cavity $(a)$ in systole and $(b)$ in diastole. the left ventricle was lined with dense calcified fibrotic tissue, about $5 \mathrm{~mm}$ thick in one case. The mitral valve was excised and the fibrous tissue below it was incised along a cleavage plane between the muscle and the scar tissue. The dissection was directed towards the ventricular apex and the posterior and anterior ventricular walls. The whole of the fibrotic area was resected, being removed like a lining (fig $2 a$ ). The mitral valve was replaced by a bioprosthetic valve in both patients.

\section{Microscopic findings}

\section{CASE 1}

Histological study of the resected tissue showed the presence of dense fibrosis with some fresh thrombus on the inner surface. Some deep elastic fibres were present, with a scanty and chronic non-specific inflammatory cell infiltrate, mainly around the blood vessels.

\section{CASE 2}

On histological examination the bulk of the tissue consisted of a thick, fibrous shell (fig $2 b$ ) with numerous vessels and scattered nodular, calcific deposits of variable size (figs $2 b$ and fig $3 a$ ). Despite the fact that no fresh endocardial thrombus was observed, the findings were consistent with a chronically organised mural thrombus. The myocardium, which was also partially resected, appeared hypertrophied. On the border between the myocardium and the thick fibrous shell some inflammatory infiltrates were detected, with a few eosinophilic granulocytes (fig $3 b$ ).

\section{Discussion}

Endomyocardial fibrosis is a restrictive cardiomyopathy commonly encountered in Central Africa, South America, and Asia, recently recognised also in the West. ${ }^{3}$ Its pathology appears to be indistinguishable from that of Loffler's endocarditis, ${ }^{4}$ and the unifying term eosinophilic endomyocardial disease has been proposed for both. ${ }^{s}$ The role of the degranulated eosinophils in 


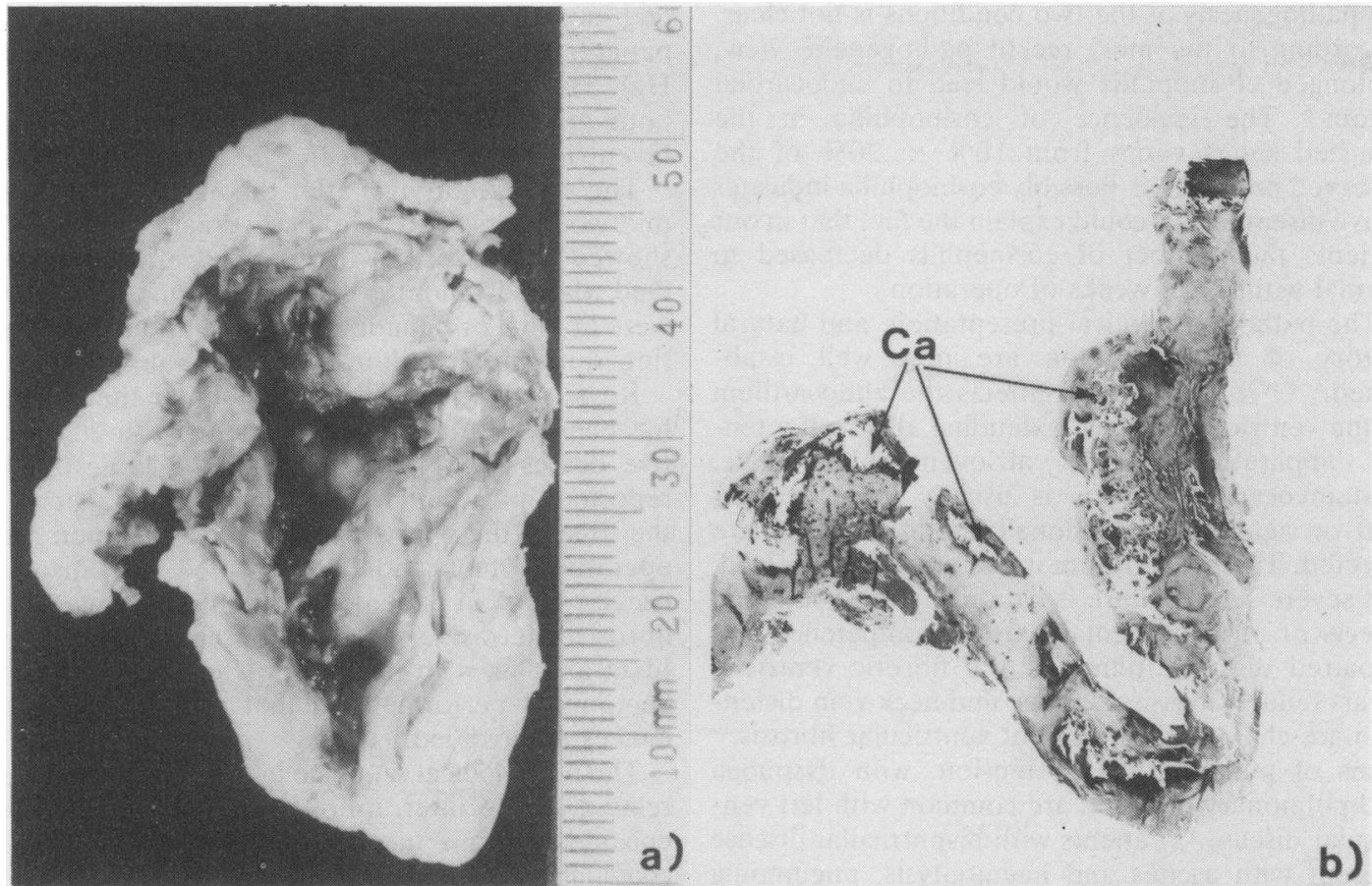

Fig 2 (a) Endocardial fibrous shell resected from the ventricular cavity in patient 2. (b) Histological section showing fibrous thickening and nodular calcific deposits. (Haematoxylin and eosin, $\times 2$.)

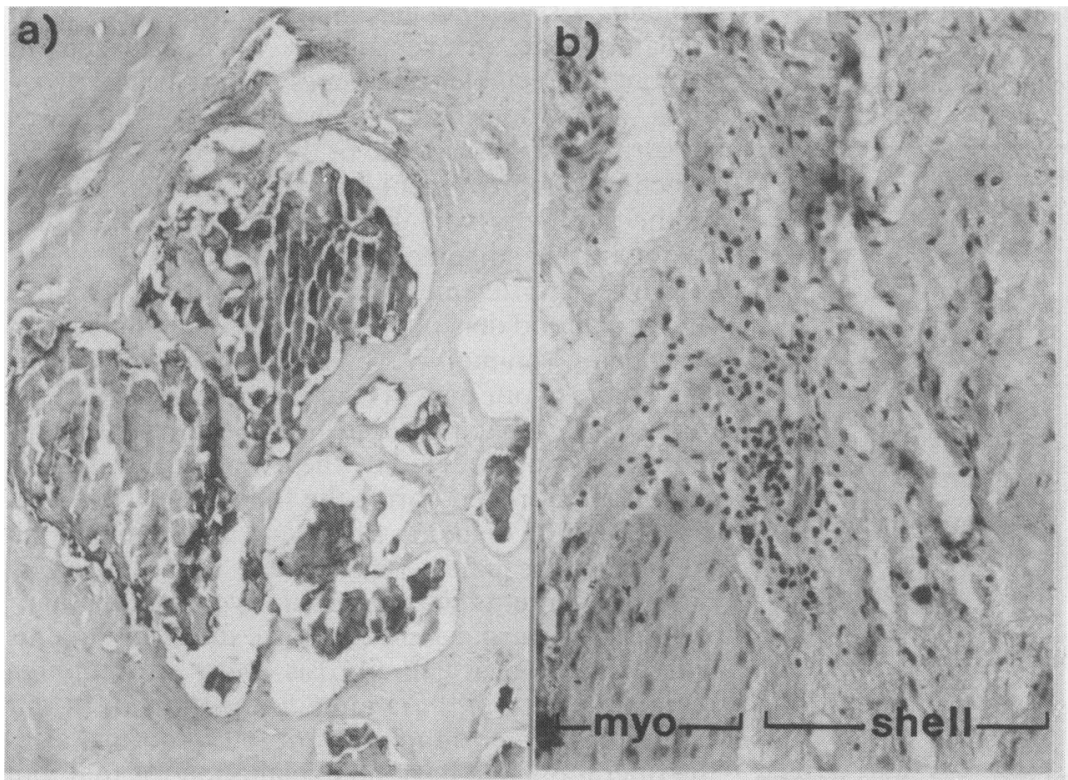

Fig 3 Microscopic appearances of the fibrous shell resected from patient 2. (a) High magnification of nodular calcific deposits. (Haematoxylin and eosin, $\times 40$.) (b) Inflammatory infiltrates at the border between myocardium and fibrous shell. Note the numerous vessels suggesting an organised thrombus.

myo-myocardium. (Haematoxylin and eosin, $\times 100$.) 
the pathogenesis of the two conditions is not clear. According to the most recent pathogenetic view, prolonged eosinophilia would lead to endocardial lesions. $^{6}$ The incidence of eosinophilia in the reported series varies from $10 \%$ to $20 \%$ of the observed patients. ${ }^{7-9}$ Possibly eosinophilia indicates active disease. This could explain the fact that in our patients the number of eosinophils decreased to normal within two weeks of operation.

The pathology, clinical presentation, and natural history of this condition are now well established. ${ }^{5-81011}$ The fibrosis affects the endocardium of the ventricular inflow, extending also to the tensor apparatus of the atrioventricular valve. Endomyocardial fibrosis is usually univentricular (left or right), but occasionally both ventricles are affected. The myocardium is not primarily affected, but severe heart failure is caused by the combined effects of atrioventricular valve incompetence and impaired diastolic filling of the fibrotic ventricle. Heart failure, massive ascites, and neck vein distension are characteristic of right ventricular fibrosis. ${ }^{10}$ Signs of pulmonary hypertension, with dyspnoea and pulmonary oedema, are common with left ventricular disease..$^{10}$ Patients with biventricular disease present with ascites and haemoptysis, pneumonia and pulmonary infarction being the most common cause of death in this condition.

In the report of Cherian and coworkers ${ }^{11}$ the mean right atrial pressure was $13.6 \mathrm{~mm} \mathrm{Hg}$ in the patients with disease on the right side and $16.4 \mathrm{~mm}$ $\mathrm{Hg}$ in those with biventricular disease. In both these groups there was a high right ventricular end diastolic pressure (mean 14.2 and $16.5 \mathrm{~mm} \mathrm{Hg}$ ). The left

Table 2 Endocardectomy for endocardial fibrosis: published results

\begin{tabular}{|c|c|c|c|c|}
\hline Authors & $\begin{array}{l}\text { No of } \\
\text { patients }\end{array}$ & $\begin{array}{l}\text { Operative } \\
\text { deaths }\end{array}$ & $\begin{array}{l}\text { Late } \\
\text { deaths }\end{array}$ & $\begin{array}{l}\text { Follow up } \\
\text { (months) }\end{array}$ \\
\hline 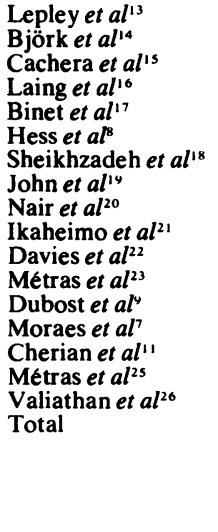 & $\begin{array}{r}1 \\
1 \\
1 \\
1 \\
1 \\
4 \\
1 \\
1 \\
1 \\
1 \\
2 \\
15 \\
20 \\
37 \\
6 \\
20 \\
17 \\
130\end{array}$ & $\begin{array}{l}0 \\
0 \\
0 \\
0 \\
0 \\
0 \\
0 \\
0 \\
0 \\
0 \\
0 \\
2 \\
3 \\
8 \\
2 \\
4 \\
5 \\
26(20 \%)\end{array}$ & $\begin{array}{l}0 \\
0 \\
0 \\
0 \\
0 \\
0 \\
0 \\
0 \\
0 \\
0 \\
0 \\
1 \\
4 \\
5 \\
-1 \\
1 \\
11 / 104 \\
\text { survivors } \\
\text { (10.5\% } \\
\text { of } \\
\text { survivors) }\end{array}$ & $\begin{array}{l}9 \\
36 \\
5 \\
\frac{1}{10} \\
36 \\
2 \\
12 \\
18 \\
14 \\
14 \\
18,9 \\
\frac{13}{48} \\
16.7 \\
\text { Mean } 18\end{array}$ \\
\hline
\end{tabular}

end diastolic pressure was high, as expected, in patients with left ventricular disease (mean $26 \mathrm{~mm}$ $\mathrm{Hg}$ ). Pulmonary hypertension was encountered in both groups of patients with left ventricular and biventricular disease (mean 57.7 and $24.5 \mathrm{~mm} \mathrm{Hg}$ ).

The average survival after the onset of symptoms in two years. ${ }^{2}$ Recently several reports ${ }^{2891225}$ showed that over $20 \%$ of non-operated patients died within 18 months of presentation; nearly $60 \%$ were in renal or hepatic failure and about $18 \%$ continued in cardiac failure during the same period.

Review of published reports shows that surgery has been performed in 130 patients with 26 operative deaths $(20 \%)$ (table 2 ). In the largest series reported' most patients showed cardiac cachexia at the time of the operation. The most common postoperative complication documented was atrioventricular block in patients with right endomyocardial fibrosis. Métras ${ }^{23}$ suggested conservation of a thin juxta-annular strip of fibrosis when right endocardectomy is performed, so that conduction disturbances are avoided.

The neurological sequelae in our first patient were related to the interruption of anticoagulants. This episode confirms the necessity of long term anticoagulation in patients who have had endocardectomy, regardless of the type of valve implanted. The rough surface left at the site of the fibrotic resection may explain the higher incidence of thromboembolism after surgery for endomyocardial fibrosis. ${ }^{7911}$

It is vital for the surgeon to find the right cleavage plane while dissecting the fibrosis if damage and perforation of the subjacent myocardium are to be avoided. Tissue and mechanical valves have been implanted for atrioventricular valve replacement without appreciable differences in the surgical prognosis. ${ }^{71223}$ A mechanical valve, however, increases the already high incidence of thromboembolism. ${ }^{7911}$ Functional improvement has been reported in most of the survivors who have been followed up..$^{711}$ Postoperative haemodynamic studies ${ }^{7911}$ have shown an improvement of cardiac output, a fall in ventricular end diastolic pressure, and an increase in ventricular volume. We observed pericardial effusion in one of our patients during the first postoperative week, probably related to poor left ventricular function as documented by the echocardiogram. His condition improved during the following weeks with diuretic and digoxin treatment. We found no "organic toxic confusional state," as observed by others in patients with preoperative eosinophilia. ${ }^{22}$ The role of steroids and cytotoxic drugs in patients with endomyocardial fibrosis with eosinophilia remains uncertain. ${ }^{23}$ As already mentioned, in our experience the eosinophil count fell to normal after the operation. We have no explanation for that, but 
no steroids or cytotoxic drugs were prescribed.

More satisfactory surgical results are obtained in patients with unilateral disease of the left ventricular type, while biventricular disease carries the worst surgical prognosis. ${ }^{7912}$ No recurrence of the disease has been reported so far during follow up of from five to 36 months. The surgical results obtained in various centres and the functional improvement shown in the survivors, compared with the poor prognosis associated with medical treatment, encourage early referral for operation in all patients with endomyocardial fibrosis who have symptoms. Although the long term results of surgery are not well established, early endocardectomy plus valve replacement must be accepted as the treatment of choice for these patients, while valve replacement alone represents an unsatisfactory palliative procedure.

\section{References}

1 Gerbaux A, Dubost C, Maurice P. Endomyocardite fibreuse observée au cours de la filariose. Ann Med Intern 1973;124:471-82.

2 D' Arbela PG, Mutazindwat T, Ptel AK, Somers K. Survival after first presentation with endomyocardial fibrosis. Br Heart J 1972;34:403-7.

3 Eterovic I, Angelini P, Leachman R, Cooley DA. Obliterative endomyocardial fibrosis. A surgical approach. Bulletin of the Texas Heart Institute 1979;6:66-8.

4 Olsen EGJ, Spry CJF. The pathogenesis of Loffler's endomyocardial disease and its relationship to endomyocardial fibrosis. In: Yu PN, Goodqin JF, eds. Progress in cardiology No 8. Philadelphia: Lea and Febiger, 1979:281-303.

5 World Health Organisation. Report of WHO/ISFC task force on the definition and classification of cardiomyopathies. Br Heart J 1980;44:672-3.

6 Libanoff A, McMahon N. Eosinophilia and endomyocardial fibrosis. Am J Cardiol 1976;37:438-41.

7 Moraes CR, Buffolo E, Lima R, et al. Surgical treatment of endomyocardial fibrosis; J Thorac Cardiovasc Surg 1983;85: 738-45.

8 Hess CM, Turina M, Senning A, Goebel NH, Schloler $Y$, Krayenbuahe HP. Pre and post operative findings in patients with endomyocardial fibrosis. Br Heart $J$ 1978;40:406-15.

9 Dubost C, Prigent C, Gerbaux A, et al. Surgical treatment of constrictive fibrous endocarditis. J Thorac Cardiovasc Surg 1981;82:585-91.

10 Wenger NK. Endomyocardial fibrosis (Davies dis- ease). In: Hurst JW, ed. The heart, arteries and veins. 3rd ed. New York: McGraw-Hill, 1974:1306-8.

11 Cherian G, Vijayaraghavan G, Krishnaswami S, et al. Endomyocardial fibrosis: report on the hemodynamic data in 29 patients and review of the results of surgery. Am Heart J 1983; 105: 706-9.

12 Bertrand E, Chauvet J, Ekra A, Métras D. Indications, contra-indications and results of surgical treatment in endomyocardial fibrosis. In: Proceedings of World Congress of Cardiology. Moscow, 1982:195.

13 Lepley D, Aris A, Korus ME, Walker JA, D'Cunha RM. Endomyocardial fibrosis. A surgical approach. Ann Thorac Surg 1974;18:626-33.

14 Björk VO, Szamosi A, Tornell G. Parietal fibroplastic endocarditis-radiological and surgical aspects. Scand J Thorac Surg 1974;8:23-6.

15 Cachera JP, Poulain H, Menashe P, Laurent F, Loisance $D$, Chiche $P$. Endocardite fibreuse d'origine filarienne-traitement chirurgical. Trop Cardiol 1976;2(6): 79-89.

16 Laing HC, Sharratt GP, Johnson AM, Davies MJ, Munro JL. Endomyocardial fibrosis in a European woman and its successful surgical treatment. $J$ Thorac Cardiovasc Surg 1977;74:803-7.

17 Binet JP, Pernod J, Kermarec J, et al. Endocardite constrictive fibroplastique. A propos d'une forme localisée au ventricle gauche. Arch Mal Coeur 1977;70:163-7.

18 Sheikhzadeh AH, Tarbiat S, Nazarian I, Aryanpur I, Senning A. Constrictive endocarditis. Report of a case with successful surgery. Br Heart J 1979;42:224-8.

19 John S, Mami GK, Muralidharan S, Krishnaswamy S, Cherian G. Endomyocardial fibrosis from a surgical standpoint. J Thorac Cardiovasc Surg 1980;80:43740.

20 Nair U, Evans T, Oakley D. Surgical treatment of endomyocardial fibrosis with preservation of the mitral valve. Br Heart J 1980;43:357-9.

21 Ikaheimo MJ, Karkola PJ, Takkunen J. Surgical treatment of Loffler's eosinophilic endocarditis. Br Heart J 1981;45:729-32.

22 Davies J, Sapsford R, Brooksby I, et al. Successful surgical treatment of two patients with eosinophilic endomycardial disease. Br Heart J 1981;46:438-45.

23 Métras D, Ouezzin-Coulibali A, Ouatarra K, Lougechand A, Chauvet J, Bertrand E. Le traitement chirurgical de la fibrose endomyocardique constrictive à propos de 15 cas. Arch Mal Coeur 1981;74:939-50.

24 Parrillo JE, Borer JS, Henry WL, Wolff SM, Fauci AS. The cardiovascular manifestations of the hypereosinophilic syndrome. Am J Med 1979; 67:572-82.

25 Métras D, Coulibaly AO, Quattaral CJ, Ekra A, Louechaud A, Bertrand E. Endomyocardial fibrosis: early and late results of surgery in 20 patients. $J$ Thorac Cardiovasc Surg 1982;83:52-64.

26 Valiathan MS, Sankarkumar R, Balakrishnan KG, Mohansingh MP. Surgical palliation for endomyocardial fibrosis: early results. Thorax $1983 ; 38: 421-7$. 